\title{
FDA subcommittee finds no evidence of PERV transmission
}

A preliminary copy of a report by the US Food and Drug Administration (FDA) subcommittee on xenotransplantation obtained by Nature Medicine finds no evidence of porcine endogenous retrovirus (PERV) genome transmission in any of the animal and human recipients of xenotransplants tested to date. The final version of the report, submitted to the FDA as the journal went to press, is expected to be crucial to the FDA's revision of the 1997 guidelines on clinical xenotransplantation, which is expected to be released next year.

While the findings can be seen as an endorsement of trials of cellular xenotic material, the document clearly states that the time is not yet right for human trials of whole organ xenotransplantation.

The subcommittee heard evidence from FDA and Centers for Disease Control and Prevention (CDC) employees, and from individuals with an interest in pushing ahead with clinical trials-patient advocates and pharmaceutical and biotechnology representatives.

All clinical xenotransplantation studies so far have involved cellular porcine material-islet cells, fetal neuronal cells and extracorporeal liver cells. No wholeorgan xenotransplant trials have been attempted, and nonhuman primate donors were ruled out by the FDA earlier this year (Nature Med. 5, 465; 1999).

The potential for PERV transmission to human cells has been a major obstacle to xenotransplant progress since its occurrence in vitro was described over two years ago (Nature Med. 3, 282; 1997). The discovery forced the FDA to suspend several clinical trials until suitable assays for PERV transmission were developed.

Hugh Auchincloss, chair of the subcommittee, says, "PERV assays employed in trials were found to be well-performed and of high quality." However, Auchincloss, who is also editor-in-chief of the journal, Xenotransplantation, told Nature Medicine that the non-transmission verdict was reached with several caveats, the most important being that "there is still no example of a transplant performed under the most risky circumstances for PERV transmission."

"Risky circumstances" include the lack of long-term xenotransplant survival and long-term immunosuppression. Other conditions that have not been part of the trials carried out so far, but that "may"

represent a risk for PERV transmission, include the inactivation of the recipients complement system by porcine tissue carrying human decay accelerating factor; removal of anti-alpha-Gal antibodies from the recipient by immunophoresis, and removal of the Gal epitope from the donor through transgenic manipulation.

The subcommittee recorded concern over the lack of positive control studies in which nonhuman primates are the recipients of pig tissue because, unlike human cells, baboon cell infection with PERV

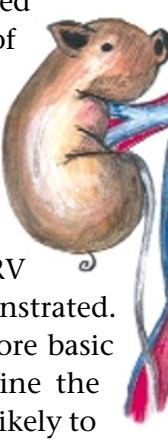
research is required to define the cell types and species most likely to be infected by PERV before evidence of no transmission can be accepted unequivocally.

In addition, the natural presence of porcine viral DNA sequences within donor cells, and the existence of donor cells within the host tissue (microchimerism), make it difficult to determine whether host infection has taken place. Therefore, PCR analysis of PERV DNA that represents infection must be standardized.

And although it recognized that assays to detect antibody responses as an indicator of PERV infection have now been developed, the group found that these assays do not reach the standard of those for other viral infections. Patient serum samples should be, says the report, banked for future analysis in the event that better assays are developed.

In addition to evidence on PERV transmission, two other topics were considered at the meeting: the potential for clinical trials of solid organ xenotransplants and the development of FDA regulatory policy.

A subset of the subcommittee was asked to consider what kind of preclinical data would be required for whole-organ trial approval. Auchincloss says there was a strong suggestion that "a standard 90 percent survival time at two months and a 50 percent survival at three months in a series of pig-to-monkey transplants, would be sufficient to justify a human bridge trial," which is a temporary pig-to-

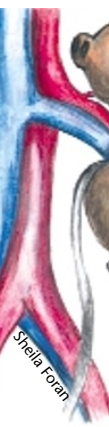

human heart transplant as an emergency measure until an allogeneic heart is available. Some of the group felt that a survival time of one year or more would be needed to justify a trial of definitive solid organ transplantation. However, Auchincloss stresses that they did not aim to reach a consensus on time-points.

Finally, it is understood that the department of Health and Human Services will set up a long-awaited national advisory committee, to be called the Secretaries Advisory Committee on Xenotransplantation (SACX), by the end of the year.

SACX would not have specific protocol approval or disapproval powers, but would have the backing of the National Institutes of Health, CDC and the FDA in its review of xenotransplantation protocols. Philip Nogouchi, director of the FDA Division of Cellular and Gene Therapies, told Nature Medicine that a notice of announcement of this committee and solicitations for nominations will appear in the Federal Register in the next few months. The FDA subcommittee members look likely to become the core of this national oversight body. The report will be avialable on http://www.fda.gov under 'Dockets'.

All eyes are now on a 160-patient retrospective study carried out by Novartis to test for any indication of clinical PERV transmission, which is expected to be published soon.

KAREN BIRMINGHAM, LONDON

\section{Scientists react to government indecision}

Britain's "anti-science climate" is to blame for the government's delay in deciding whether to permit research into the therapeutic use of human embryonic stem cells. This is the conclusion of several leading UK researchers, including at least one for whom that atmosphere has now become intolerable.

Roger Gosden, a professor of reproductive biology at the University of Leeds and a pioneer of ovarian tissue transplant techniques, is leaving Britain for Canada in the fall. The announcement on June 24th that the government has decided to 